\title{
KOMUNIKASI PERSUASIF PADA HUBUNGAN INTERPERSONAL PEROKOK AKTIF DAN PASANGANNYA
}

\author{
Hanafiah Ali ${ }^{1}$, Chatia Hastasari ${ }^{2}$ \\ ${ }^{1}$ Jurusan Ilmu Komunikasi, Fakultas Ilmu Sosial, \\ Universitas Negeri Yogyakarta, Yogyakarta. \\ Email: Hanafiah.ali2016@student.uny.ac.id
}

\begin{abstract}
ABSTRAK
Penelitian ini bertujuan untuk mengetahui bagaimana kedekatan hubungan interpersonal antara perokok aktif dengan pasangannya yang merupakan perokok pasif dan untuk mengetahui serta memahami bagaimana komunikasi persuasif yang dilakukan antara pasangan perokok pada kalangan mahasiswa Universitas Negeri Yogyakarta dalam upayanya untuk berhenti merokok. Penelitian yang dilakukan di Universitas Negeri Yogyakarta (UNY) ini menggunakan pendekatan deskriptif kualitatif dengan informan perokok aktif dan pasangannya di kalangan mahasiswa UNY yang berjumlah 8 pasangan. Metode pengumpulan data penelitian ini menggunakan Focus Group Discussion (FGD) dengan pengambilan data purposive sampling dan keabsahan data menggunakan triangulasi sumber. Analisis data penelitian ini dilakukan dengan mengumpulkan data, mereduksi data, menyajikan data, dan menarik kesimpulan. Hasil dari penelitian ini menunjukkan hubungan interpersonal antara perokok aktif dan pasangannya di kalangan mahasiswa UNY adalah 1) keterbukaan secara langsung, berupa saran dan nasihat dari aktivitas merokok; 2) komunikasi persuasif melalui media, berupa saran, nasihat, informasi rokok dan dampak bahaya merokok; 3) komunikasi persuasif melalui ancaman dan sanksi berupa pemutusan hubungan untuk merubah sikap dan tingkah laku; 4) komunikasi persuasif melalui sindiran, berupa perkataan langsung tentang sisi negatif merokok terhadap kesehatan; 5) komunikasi persuasif melalui gombalan, berupa gombalan romantis untuk menarik perhatian, dan menghindari salah persepsi; 6) komunikasi persuasif melalui games, berupa nasihat melalui sebuah permainan kejujuran; 7) komunikasi persuasif melalui perumpamaan, berupa tindakan pertukaran posisi antara perokok aktif dan pasangannya; dan 8) komunikasi persuasif melalui pengalaman orang lain, berupa nasihat dari contoh dan cerita nyata tentang dampak bahaya merokok.
\end{abstract}

Kata Kunci: Hubungan Interpersonal, Komunikasi Interpersonal, Komunikasi Persuasif, Perokok Aktif, Perokok Pasif

\section{PERSUASIVE COMMUNICATION IN INTERPERSONAL RELATIONSHIOP BETWEEN AN ACTIVE SMOKER AND HIS PARTNER}

\begin{abstract}
This study aims to find out how the extent of the closeness of interpersonal relationship between an active smoker to his partner that is a passive smoker, then to find out and to understand how persuasive communication is carried out by them as the students of Yogyakarta State University in the context of an effort to stop smoking. The study that was conducted in Yogyakarta State University used a descriptive qualitative approach with informants of active smokers and their partners among the students of Yogyakarta State University (eight couples). The data were collected by doing Focus Group Discussion (FGD) with purposive sampling data collection and data validity by using source triangulation. The data analysis of this study was conducted by collecting and reducing data, presenting data, and drawing conclusions. The findings of this study show that a persuasive communication of interpersonal relationship between an active smoker to his partner as the students of Yogyakarta State University, are a direct communication openness in the form of advice and suggestion of smoking activities; persuasive communication through the media in the form of advice, suggestion, and information of cigarette and the effects of the danger of smoking; persuasive communication through threats and penalty in the form of termination of relationship in order to change the smokers' attitude and behavior; persuasive communication through innuendo in the form of direct words about the negative effects of smoking for health; persuasive communication through flattery in the form of romantic words to attract the smokers' attention and avoid misunderstanding; persuasive communication through games in the form of advice through the honesty game; persuasive communication through what-if-scenario in the form of the act of exchanging
\end{abstract}


positions between active smokers and their partners; and persuasive communication through the other people's experiences in the form of advice by telling the true stories and the examples about the bad effects of smoking.

Keywords: Persuasive Communication, Interpersonal Relationship, Persuasive Communication, Active Smoker, Passive Smoker

Korespondensi: Hanafiah Ali, Chatia Hastasari S.Sos,. M.I.Kom. Universitas Negeri Yogyakarta Jl. Colombo No.1, Karang Malang, Caturtunggal, Kec. Depok, Kab. Sleman, Daerah Istimewa Yogyakarta 55281. No. Hp, Whatsapp: 081392940232 Email: Hanafiah.ali2016@ studentuny.ac.id

\section{PENDAHULUAN}

Komunikasi merupakan hal yang tidak dapat dihindari oleh manusia, terutama dalam keberlangsungan kehidupan sehari-hari yang sangat membutuhkan aspek komunikasi. Namun kadangkalah komunikasi dalam kehidupan seharihari menjadi kurang efektif dikarenakan terdapat gangguan atau noise. Aw (2011: 9) menjelaskan bahwa gangguan atau noise merupakan apa saja yang menganggu atau membuat kacau proses penyampaian dan penerimaan pesan baik yang bersifat fisik dan phsikis. Noise juga dapat terjadi dalam komponen-komponen bahkan sistem komunikasi.

Menurut Effendy (2003) dalam Saputra (2017: 07), komunikasi yang efektif dapat menimbulkan pengertian, kesenangan, pengaruh pada sikap, hubungan yang makin baik dan tindakan. Hal serupa dinyatakan oleh Aw (2010: 22), bahwa kedudukan manusia sebagai makhluk sosial juga berpengaruh terhadap pentingnya komunikasi yang terjadi dalam kehidupan seharihari. Hal ini berarti sebagai makhluk sosial manusia tidak bisa hidup tanpa orang lain, karena pasti akan berhubungan atau berinteraksi dengan semua orang termasuk di dalamnya adalah teman, sahabat, dan pasangan. Oleh sebab itu dalam diri manusia pasti terdapat kemampuan, keahlian, dan keterampilan yang berbeda-beda pada setiap individu untuk saling melengkapi serta menolong dalam menjalani kehidupan sehari-hari.

Begitu pula yang terjadi di lingkungan mahasiswa, komunikasi tentu sangat dibutuhkan untuk keberlangsungan pertukaran informasi atau penyampaian pesan baik itu secara kelompok maupun personal. Dalam hal ini komunikasi persuasif turut berperan dalam komunikasi yang terjadi di kalangan mahasiswa. Menurut Nurhayani (2016: 14) komunikasi persuasif merupakan proses interaksi yang terjadi pada dua orang atau lebih yang di dalamnya lebih mengedepankan sebuah pendekatan yaitu ajakan atau bujukan untuk mencapai kesamaan pemaknaan di antara kedua belah pihak. Dari penjelasan tersebut maka dapat dikatakan bahwa komunikasi sangat membantu individu dalam menjalani kehidupan sosialnya, salah satunya yaitu komunikasi persuasif.

Salah satu fenomena yang menarik khususnya terjadi di lingkungan mahasiswa adalah perilaku merokok. Sebenarnya perilaku merokok ini dapat kita jumpai dengan mudah pada kehidupan seharihari baik itu di lingkungan tempat tinggal, tempat umum, dan sekolah atau universitas. Menurut Astuti, Susanti, dan Elista (2016: 23) merokok sudah menjadi salah satu gaya hidup yang tren 
saat ini, khususnya di Indonesia. Hal ini dapat dilihat dengan tingginya tingkat perokok aktif, tidak hanya pada perokok aktif berjenis kelamin laki-laki, tetapi juga perempuan.

Setyanda, Sulastri, Lestari (2015: 436) mengatakan perokok dapat dibedakan dalam beberapa kategori, salah satunya yaitu dibagi berdasarkan cara bahan kimia yang ada di dalam rokok itu masuk ke dalam tubuh seseorang, dalam hal ini dapat dibedakan menjadi dua yaitu: (1) Perokok aktif, merupakan individu yang merokok dan langsung menghisap rokok tersebut, hal ini tentunya bisa menimbulkan dampak bahaya terhadap kesehatan orang yang mengonsumsinya maupun pada lingkungan sekitar. (2) Perokok pasif, sedangkan perokok pasif itu adalah seseorang yang menghirup asap rokok namun orang tersebut bukanlah perokok, asap rokok yang terhirup dari perokok aktif ini mengandung lima kali lebih banyak karbon monoksida, serta mengandung tar dan nikotin sebanyak empat kali lebih banyak dari perokok aktif yang merokok.

Menurut Yenti \& Afandi, (2015) rokok dan merokok merupakan masalah yang masih sulit diselesaikan hingga saat ini. Padahal rokok memiliki dampak dan bahaya bagi mereka yang mengonsumsinya, bahaya merokok ini sebenarnya sudah banyak sekali disampaikan kepada masyarakat, contohnya yaitu melalui campaign, sosialisasi, dan seminar. Namun pada kenyataannya kebiasaan merokok yang terjadi pada masyarakat masih sangat sulit untuk dihentikan, walaupun banyak sekali pihak yang menyampaikan ketidaknyamanan mereka saat berpapasan dengan orang yang merokok. Yenti \&
Afandi, (2015) juga mengatakan bahwa bahaya merokok tidak hanya terjadi pada perokok itu sendiri namun juga memiliki dampak pada orangorang di sekelilingnya. Hal ini tentu akan berpengaruh pada kehidupan sosial individu yang menjadi perokok aktif dan juga perokok pasif tersebut. Selain memiliki dampak sosial, rokok juga memiliki dampak terhadap kesehatan manusia salah satunya adalah berisiko untuk terkena penyakit. Center for The Advancement of Health dalam Citi Chotidjah, (2013) mengatakan ada beberapa penyakit yang berisiko untuk menyerang kesehatan perokok aktif yaitu kanker hati dan paru, bronkitis kronis, emphysema, gangguan pernafasan, kerusakan dan luka bakar, berat badan rendah dan perkembangan yang terhambat pada bayi. Sejalan dengan itu, Benny \& Kennedy (2016: 13) mengatakan berawal dari mencoba sebatang rokok dan rasa penasaran, seseorang dapat mencoba dan terjerumus ke jenisjenis lain seperti ganja, sabu-sabu, ekstasi, dan putaw.

Menurut data Global Youth Tobacco Survey (GYTS) 2014, terdapat 18,3 persen pelajar di Indonesia sudah mempunyai kebiasaan merokok, dengan persentase jenis kelamin laki-laki sebanyak 33,9 persen dan perempuan 2,5 persen, dengan jumlah rata-rata data perokok masyarakat Indonesia sekitar 30 persen adalah usia 15 tahun ke atas, dari data ini dapat dikatakan bahwa seiring bertambahnya umur pada masyarakat Indonesia maka persentase dari perokok akan terus meningkat. Mengutip dari Hapsari, Haikal (2018) hal ini sejalan dengan apa yang diungkapkan Prof dr. Tjandra Yoga Aditama, 
SpP(K), MARS, DTM\&H, DTCE, Kepala Badan

Penelitian dan Pengembangan Kesehatan Kementerian Kesehatan, keterangan pers yang diterima CNN Indonesia.

“... Artinya, bila kita dapat menekan kebiasaan merokok pada kaum muda atau pelajar, maka kita dapat juga mengharapkan angka perokok pada dewasa dapat dikendalikan lebih baik. Dalam hal ini, program penanggulangan merokok di lingkungan sekolah punya peran cukup besar. Jangan ada guru dan murid yang merokok di lingkungan sekolah, jangan ada penjual rokok di sekitar sekolah dan juga ada pengetahuan tentang rokok yang diajarkan pada siswa sekolah..."

Menurut data dari Riskesdas 2013 di Daerah Istimewa Yogyakarta menunjukkan bahwa jumlah rumah bebas asap rokok pada tahun 2012 (46.67\%) cenderung mengalami penurunan jika dibandingkan dengan tahun 2011 (66.1\%). Namun persentase merokok penduduk usia 15 - 19 tahun sebesar 21,3\%. Sedangkan data dari Susenas 2017, menunjukkan bahwa persentase penduduk 5 tahun ke atas yang merokok tembakau selama sebulan terakhir menurut kabupaten/kota dan kebiasaan merokok pada survei ke 100 orang mendapatkan hasil bahwa di Kabupaten Sleman terdapat $16,32 \%$ menyatakan merokok setiap hari dan 2,89\% merokok namun tidak setiap hari. Dari data ini dapat diketahui bahwa perokok aktif yang ada di Indonesia khususnya di Daerah Istimewa Yogyakarta masih cukup tinggi terutama pada usia 15 - 19 tahun, dimana usia ini merupakan usia peralihan dari masa remaja menuju dewasa. Sebagai tempat yang mendapat julukan Kota pelajar, hal ini tentu sangat mengganggu karena sebagaimana kita ketahui di Yogyakarta sendiri terdapat banyak sekali individu-individu yang latar belakang pendidikanya sudah baik terutama mahasiswa, namun data-data di atas menunjukkan bahwa masih kurangnya kesadaran mereka terhadap dampak dan bahaya dari merokok.

Sangat disayangkan fenomena merokok ini juga terjadi pada mahasiswa Universitas Negeri Yogyakarta yang merupakan perguruan tinggi negeri dengan mahasiswa terbanyak kedua di Kabupaten Sleman, Daerah Istimewa Yogyakarta dengan total mahasiswa sebanyak 26.234 (Ristekdikti pada 4 Oktober 2019). Berdasarkan penelitian dari Prihatin (2012: 39) tentang kebiasaan merokok pada mahasiswa di Fakultas Ilmu Pendidikan UNY dengan tiga subjek utama yaitu perokok aktif dari Fakultas Ilmu Pendidikan UNY dan tiga informan perokok aktif yang menjadi pendukung dari subjek penelitian dari luar UNY dan FIP UNY, mengatakan bahwa mereka melakukan kegiatan merokok sebagai suatu kebiasaan dan susah untuk ditinggalkan.

Tidak hanya itu penelitian dari Septiana (2013: 80) yang meneliti tentang perokok aktif di kalangan mahasiswa khususnya mahasiswa UNY, juga mendapatkan hasil bahwa dari 30 informan mahasiswa UNY yang merupakan perokok aktif (26 laki-laki dan 4 perempuan), terdapat 24 informan (80\%) yang merokok dengan jenis filter, 1 informan (3,3\%) merokok dengan jenis non filter, kemudian terdapat 16 informan $(53,3 \%)$ merokok selama 1-5 tahun, 11 informan $(36,7 \%)$ merokok selama 5-10 tahun, dan 3 informan (10\%) merokok selama lebih dari 10 tahun. Sedangkan jika dilihat dari banyaknya rokok yang dihisap perharinya dari 30 informan tersebut terdapat 28 informan $(93,3 \%)$ merokok sebanyak 
satu bungkus perharinya dan 2 informan $(6,7 \%)$ merokok sebanyak 2 bungkus perharinya.

Dari kedua penelitian ini dapat dikatakan bahwa tingkat perokok aktif yang ada di Universitas Negeri Yogyakarta masih sangat tinggi, itu terjadi tidak hanya pada laki-laki namun juga perempuan, dan permasalahannya adalah mereka yang merupakan perokok aktif tidak segan untuk melakukan kegiatan merokoknya di lingkungan kampus khususnya kantin yang merupakan tempat umum bagi mahasiswa UNY. Oleh karena itu komunikasi yang terjalin antara perokok aktif dan pasangannya berpengaruh untuk mengurangi intensitas merokok terutama pada kalangan mahasiswa UNY.

Pada sebuah proses komunikasi yang terjadi antara individu atau kelompok khususnya mahasiswa UNY di dalamnya pasti terdapat hubungan interpersonal khususnya pasangan. Hubungan interpersonal inilah yang nanti akan memberikan pengaruh terhadap sebuah permasalahan yang sedang terjadi dalam sebuah hubungan tersebut. Saputra (2017: 10) mengatakan bahwa hubungan interpersonal sangat penting dibangun dan ditingkatkan dengan menyelaraskan hubungan individu satu dengan yang lain dan membangun kerjasama yang efektif dengan berbagai pihak yang ada. Berdasarkan penelitian yang dilakukan oleh Sary dan Nuryani (2014: 172) yang menguji tentang hubungan faktor interpersonal dengan komitmen pencegahan tersier pada siswa perokok. Menurut Suyitno (1989) dalam Sary dan Nuryani (2014: 169) menyatakan bahwa pencegahan tersier adalah suatu tindakan untuk meminimalisir komplikasi agar mampu meningkatkan kualitas hidup dan diterima oleh lingkungan sekitar. Penelitian ini mendapatkan hasil yaitu distribusi frekuensi mengenai faktor interpersonal didapatkan lebih banyak responden yang berkomitmen untuk pencegahan tersier sebesar 56.7\%. Artinya hubungan interpersonal sangat memiliki pengaruh yang besar dalam pecegahan perokok aktif untuk berhenti merokok. Namun sayangnya hal ini kurang ditekankan untuk membantu perokok aktif agar bisa mengurangi kebiasaan merokok atau mungkin berhenti merokok, karena selama ini peningkatan kesadaran untuk berhenti merokok misalnya melalui campaign atau sosialisasi masih belum melibatkan kedekatan hubungan interpersonal perokok aktif dan pasif terutama pasangan, dan kebanyakan hanya mengutarakan tentang dampak bahaya merokok bagi kesehatan.

Dengan adanya masalah atau fenomena tersebut maka penelitian ini berguna untuk mengkaji lebih dalam tentang komunikasi yang efektif dalam mengatasi masalah tingginya tingkat merokok yang ada di kalangan mahasiswa UNY, karena dalam kehidupan mahasiswa pasti terdapat suatu hubungan interpersonal salah satunya adalah pasangan (pacar), khususnya yang terjadi pada perokok aktif dan perokok pasif. Tentunya ini dapat dilihat dalam konteks komunikasi persuasif dalam hubungan interpersonal tentang bagaimana dampak yang terjadi terhadap perokok aktif dan perokok pasif yang ada pada kalangan mahasiswa Universitas Negeri Yogyakarta.

\section{METODE PENELITIAN}

Penelitian ini merupakan penelitian deskriptif dengan pendekatan kualitatif. Pontoh 
(2013) mengatakan bahwa penelitian kualitatif adalah suatu penelitian kontekstual yang menjadikan manusia sebagai instrumen, dan disesuaikan dengan situasi yang wajar dalam kaitannya dengan pengumpulan data yang pada umumnya bersifat kualitatif.

Metode pengumpulan data yang digunakan dalam penelitian ini adalah Focus Group Discussion (FGD) dengan informan sebanyak delapan pasangan perokok aktif dan pasif. Afiyanti (2008: 58) mengatakan bahwa Focus Group Discussion (FGD) atau diskusi kelompok terfokus merupakan suatu metode pengumpulan data yang lazim digunakan pada penelitian kualitatif sosial, tidak terkecuali pada penelitian komunikasi juga, metode ini mengandalkan perolehan data atau informasi dari suatu interaksi informan atau responden berdasarkan hasil diskusi dalam suatu kelompok yang berfokus untuk melakukan bahasan dalam menyelesaikan permasalahan tertentu. Sedangkan teknik pengumpulan data menggunakan purposive sampling.

\section{HASIL DAN PEMBAHASAN}

Berdasarkan penyajian data di atas dapat diketahui bahwa hubungan interpersonal antara pasangan perokok pasif dan perokok aktif di kalangan mahasiswa UNY terdiri dari tiga tahapan yaitu tahapan pembentukan hubungan atau perkenalan, tahapan peneguhan hubungan, dan tahapan pemutusan hubungan.

Hubungan interpersonal yang dijalin oleh perokok pasif dengan pasangannya merupakan hubungan yang dekat, kuat, dan erat. Hal ini bisa dilihat dari topik obrolan yang dilakukan seperti membahas tentang masa depan ketika perokok pasif dan pasangannya sudah memiliki anak dan anak tersebut terkena dampak bahaya merokok. Seperti yang diungkapkan oleh Agba (2018: 76) bahwa hubungan interpersonal adalah hubungan yang intim, kuat, dan dekat. Oleh karena itu hubungan yang erat ini digunakan untuk membahas aktivitas merokok dari pasangannya yang merupakan perokok aktif.

Hubungan interpersonal yang dilakukan oleh perokok pasif kepada pasangannya yang merupakan perokok aktif dimulai dengan saling berkenalan. Dari perkenalan tersebut kemudian perokok pasif dan pasangannya mengenal lebih dalam tentang masing-masing dari mereka. Sehingga terjadi pertukaran informasi, khususnya informasi tentang aktivitas merokok dari perokok aktif.

Selain melakukan perkenalan, hubungan interpersonal yang dijalin oleh perokok pasif dan pasangannya juga melakukan beberapa hal seperti mengakrabkan hubungan yang dijalani. Hal ini dilakukan oleh perokok aktif dengan berkomunikasi secara langsung kepada pasangannya dan memposisikan dirinya sebagai teman, terutama dalam hal membahas aktivitas merokoknya.

Berdasarkan keakraban yang terjalin, perokok pasif dapat melakukan kontrol terhadap aktivitas merokok dari pasangannya. Hal ini dilakukan dengan memberikan nasihat berupa dampak bahaya merokok kepada pasangannya yang berhubungan dengan kesehatan perokok aktif tersebut. Ketika memberikan nasihat kepada pasangannya, perokok pasif juga lebih bersikap 
hati-hati, karena respon yang kurang tepat dapat memicu permasalahan pada hubungan yang dijalin. Namun sebaliknya ketika respon yang diberikan perokok pasif kepada pasangannya tepat dan sesuai, maka perokok aktif cenderung menghargai pasangannya yang merupakan perokok pasif. Selain itu nada emosional yang diberikan oleh perokok pasif kepada pasangannya juga ikut berpengaruh terhadap hubungan mereka. Hal ini terbukti ketika nada emosional tersebut tepat dan teratur maka perokok aktif akan lebih menghargai pasangannya ketika membahas aktivitas merokoknya.

Perbedaan nilai berupa perbedaan budaya dari perokok pasif dengan pasangannya juga merupakan hal yang mempengaruhi hubungan yang dijalin. Namun pengaruh yang disebabkan oleh perubahan budaya ini tidak begitu signifikan. Karena permasalahan ini dapat diselesaikan dengan komunikasi yang baik dari perokok pasif kepada pasangannya. Hal ini sesuai dengan pernyataan Rakhmat (2005: 125) yang menyebutkan bahwa terdapat tiga tahapan dalam sebuah hubungan interpersonal yang sedang berlangsung, yaitu pembentukan hubungan atau tahap perkenalan, peneguhan hubungan, dan pemutusan hubungan.

Pada hubungan interpersonal perokok pasif dan pasangannya juga terdapat komunikasi persuasif. Komunikasi persuasif ini dilakukan untuk mempengaruhi perokok aktif dalam aktivitas merokoknya. Perokok pasif melakukan komunikasi persuasif kepada pasangannya dengan cara memberikan pesan secara langsung. Hal ini dilakukan agar efek dan reaksinya dapat dilihat secara langsung. Komunikasi persuasif secara langsung ini juga dilakukan secara terbuka oleh perokok pasif dan pasangannya, agar kedua belah pihak dapat saling bertukar informasi mengenai aktivitas merokok yang ada. Keterbukaan itulah yang ternyata membuat perokok pasif dan pasangannya mendapatkan kepuasan tersendiri.

Tidak hanya melakukan komunikasi persuasif secara langsung perokok pasif juga menggunakan media sebagai perantara komunikasi persuasif yang disampaikan. Seperti memberikan informasi dan nasihat tentang dampak bahaya merokok melalui media sosial Whatsapp, Twitter, dan Instagram. Informasi atau nasihat yang diberikan berupa screenshoot tentang dampak bahaya merokok dan meme atau lelucon tentang rokok.

Nasihat berupa sindiran juga dilakukan perokok pasif kepada pasangannya yang merupakan perokok aktif. Sindirian yang diberikan adalah perkataan langsung tentang sisi negatif dari aktivitas merokok.

Gombalan romantis juga dilakukan perokok pasif kepada pasangannya dalam menyampaikan nasihat terhadap aktivitas merokok dari perokok aktif. Gombalan tersebut berupa perkataan romantis yang membahas tetang rasa keinginan perokok pasif untuk menjalin hubungan lebih lama dengan pasangannya. Selain itu gombalan seperti nasihat untuk menyayangi diri terlebih dahulu baru menyayangi pasangannya. Ini digunakan untuk mempengaruhi perokok aktif agar mengurangi dan berhenti dari aktivitas merokoknya tanpa harus menyingung perokok aktif tersebut. 
Hal menarik lainnya yang dilakukan oleh perokok pasif kepada pasangannya dalam menyampaikan pesan atau nasihat terhadap aktivitas merokoknya adalah dengan menerapkan sebuah games (permainan). Games tersebut berupa pemberian hadiah jika perokok aktif mematuhi aturan untuk selalu jujur dalam aktivitas merokoknya, namun ketika aturan tersebut dilanggar maka perokok aktif harus menerima hukuman dari pasangannya yang merupakan perokok pasif. Komunikasi persuasif seperti ini digunakan agar perokok aktif tidak merasa bosan dan tersingung terhadap pesan atau nasihat yang disampaikan oleh pasangannya.

Selain games, komunikasi persuasif melalui perumpamaan juga dilakukan perokok pasif dan perokok aktif dalam membahas aktivitas merokok yang dilakukan oleh perokok aktif. Perumpamaan yang dilakukan perokok pasif kepada pasangannya ini seperti membalikkan posisi perokok pasif sebagai orang yang terkena paparan asap rokok, dengan posisi perokok aktif sebagai orang yang menghisap dan menyebarkan asap rokok tersebut. Dari hal ini ternyata memberikan pengaruh terhadap hubungan yang dijalin, terutama tentang masa depan dari hubungan tersebut. Hal tersebut kemudian merubah pemikiran perokok aktif untuk mengurangi atau bahkan berhenti dari aktivitas merokoknya, karena perokok aktif juga ingin menjalin hubungan yang lebih lama dengan pasangannya yang merupakan perokok pasif.

Komunikasi persuasif yang dilakukan perokok pasif kepada pasangannya tidak hanya melalui pendapat dari perokok pasif itu sendiri, melainkan pesan dan nasihat tersebut disampaikan dengan melihat pengalaman orang lain. Pengalaman orang lain tersebut seperti korban yang terkena penyakit kronis dari dampak bahaya merokok yaitu ayah daru perokok pasif itu sendiri. Selain itu pengalaman orang lain berupa mantan perokok aktif yang berhasil berhenti dari aktivitas merokok. Pengalaman-pengalaman yang ada di kehidupan nyata itulah yang kemudian digunakan perokok pasif untuk menyampaikan pesan dan nasihat kepada pasangannya yang merupakan perokok aktif. Hal ini dilakukan agar pengaruh yang didapat lebih signifikan karena berasal dari kisah nyata orang lain. Menurut Effendy (2016: 8), komunikasi persuasif merupakan satu dari empat macam teknik komunikasi, diantaranya: komunikasi informatif; komunikasi instruktif atau koersif; komunikasi persuasif; dan hubungan manusiawi.

Teknik komunikasi persuasif yang dilakukan perokok pasif kepada pasangannya adalah dengan memberikan pesan serta nasihat yang dilakukan dengan beberapa cara seperti melalui sindiran, gombalan romantis, games, perumpamaan, dan pengalaman orang lain. Dari penjabaran di atas, komunikasi persuasif yang dilakukan perokok pasif kepada pasangannya dilakukan dengan berbagai macam teknik komunikasi. Hal ini dilakukan perokok pasif kepada pasangannya agar bisa mengurangi bahkan berhenti dari aktivitas merokoknya.

\section{SIMPULAN}

Dari penjelasan di atas maka dapat ditarik kesimpulan secara menyeluruh bahwa komunikasi persuasif dalam hubungan interpersonal yang baik 
antara perokok aktif dan pasangannya yang merupakan perokok pasif dapat menimbulkan pengurangan intensitas merokok dari perokok aktif.

\section{DAFTAR PUSTAKA}

Buku :

Aw, Suranto. (2010). Komunikasi sosial budaya. Yogyakarta: Graha Ilmu.

Aw, Suranto. (2011). Komunikasi interpersonal. Yogyakarta: Graha Ilmu.

Benny Pattinasarany, Kennedy Jennifer Dhillon. (2016). Dream and destiny. Yogyakarta: Penerbit ANDI

Effendy, Onong Echjana. (2016). Ilmu komunikasi: Teori dan praktek. Bandung: Remaja Rosdakarya.

Miles, M. B, \& Huberman, A. M. (1992). Analisis data kualitatif. Terjemahan oleh Tjetjep Rohandi Rohidi. Jakarta: Universitas IndonesiaI Press.

Rakhmat, J. (2005). Psikologi komunikasi. Bandung: PT. Remaja Rosdakarya.

Sugiyono. (2016). Metode penelitian kuantitatif, kualitatif, dan R\&D. Bandung. CV Alfabeta.

\section{Internet :}

World Health Organization, Regional Office for South-East Asia. Global Youth Tobacco Survey (GYTS): Indonesia report, 2014. New Delhi: WHO-SEARO, 2015.

http://www.depkes.go.id/resources/download/profil/PR OFIL_KES_PROVINSI_2017/14_DIY_2017.pdf (diakses pada 13/03/19 22.02 WIB)

Forlap.ristekdikti.go.id (diakses pada 4/10/19 19.29 WIB)

Jurnal :

Agba, M. S., PhD. (2018). Interpersonal relationships and organizational performance: The nigerian public sector in perspective. Indian Journal of Commerce and Management Studies, 9(3), 75-83.

Aditama, TY. (1996). Rokok dan permasalahannya di indonesia. Jurnal Respirologi Indonesia, 16(3).

Afiyanti, Y. (2008). Focus group discussion (diskusi kelompok terfokus) sebagai metode pengumpulan data penelitian kualitatif. Jurnal Keperawatan Indonesia, 12(1), 58-62.
Bolong, J., Tamam, E., \& Hassan, M. S. (2010). Strategi meningkatkan hubungan interpersonal dalam talian dalam kalangan remaja Malaysia. Jurnal Pengajian Media Malaysia, Jilid, 12, 91109.

Chotidjah, S. (2013). Pengetahuan tentang rokok, pusat kendali kesehatan eksternal dan perilaku merokok. Hubs-Asia, 10(1).

Elista, R. (2016). Gambaran paparan asap rokok pada ibu hamil berdasarkan usia kehamilan di desa cintamulya kecamatan jatinangor kabupaten sumedang. Jurnal Sistem Kesehatan, 2(1).

Fatmawati, Z. A., Pradekso, T., Setyabudi, D., \& Lailiyah, N. (2014). Pengaruh terpaan peringatan pesan pada iklan rokok terhadap sikap untuk berhenti merokok pada remaja. Interaksi Online, 8(4).

Hapsari, A., \& Muhammad, A. H. (2018). Keputusan mahasiswa universitas " $\mathrm{x}$ " bandung untuk merokok di lingkungan kampus yang dipengaruhi oleh faktor sosial. ULTIMA Management, 10(1), 44-51.

Nurhayani, Nurhayani (2016). Pengaruh penerapan komunikasi persuasif terhadap kinerja pegawai di kantor dinas kependudukan dan catatan sipil kota makassar. Undergraduate (S1) thesis, Universitas Islam Negeri Alauddin Makassar.

Pontoh, W. P. (2013). Peranan komunikasi interpersonal guru dalam meningkatkan pengetahuan anak. Jurnal Acta Diurna, 2(1).

Purwanti, N. (2015). Interpersonal relationship di kalangan perokok aktif wanita (studi deskriptif kualitatif pada perokok aktif wanita kedai kebun forum yogyakarta).

Prihatin, Arif. (2012). Kebiasaan merokok pada mahasiswa (studi kasus pada mahasiswa fakultas ilmu pendidikan). Skripsi S1, Universitas Negeri Yogyakarta.

Rahardjo, M. (2010). Triangulasi dalam penelitian kualitatif.

Santi, Y. (2015). Peran komunikasi interpersonal dalam menjaga hubungan yang harmonis antara mertua dan menantu perempuan. Fakultas Ilmu Sosial dan Ilmu Politik, 4(3). 
Sary, L., \& Nuryani, D. D. (2014). Hubungan faktor interpersonal dengan komitmen pencegahan tersier pada siswa perokok di kota bandar lampung tahun 2013.

Saputra, A. G. E., Setyawan, S., \& Kom, M. I. (2017). Komunikasi interpersonal orang tua dengan anak perokok aktif usia dini (studi deskriptif kualitatif komunikasi interpersonal orang tua dengan anak perokok aktif usia 13-17 tahun di desa ngreden kecamatan wonosari kabupaten klaten). (Doctoral dissertation, Universitas Muhammadiyah Surakarta).

Setyanda, Y. O. G., Sulastri, D., \& Lestari, Y. (2015). Hubungan merokok dengan kejadian hipertensi pada laki-laki usia 35-65 tahun di Kota Padang. Jurnal kesehatan andalas, 4(2).

Septiana, E. P. (2013). Hubungan perilaku merokok dengan fungsi paru mahasiswa uny sebagai bahan penyusunan modul pengayaan materi kelainan sistem pernapasan pada manusia bagi siswa sma kelas xi ipa semester ii. Skripsi S1. Universitas Negeri Yogyakarta.

Yenti, D. R., \& Afandi, D. (2015). Gambaran siswa/siwsi sekolah menengah pertama terhadap perilaku merokok di kotamadya pekanbaru. Jurnal Online Mahasiswa (JOM) Bidang Kedokteran, 2(2), 1-14. 